\title{
ABORTIFACIENT EFFECTS OF Ananas ananassoides BAK. (Ananai) IN RATS.
}

\author{
Luiza NAKAYAMA', Josẻ Silva de SOUZA', Otavio Mitio OHASHI', William \\ G. VALE ${ }^{1}$
}

\begin{abstract}
The tea made from the infrutescense (corresponding to the edible part plus its cover) of ananai (Ananas ananassoides BAK.) was administered to pregnant rats, during the period of embryos implantation (5th - 6th day through pregnancy). The animals were slaughtered on the 14th - 15th day through the pregnancy and average rates of implantation and resorption were stimated.

The results showed that this plant has an effective abortifacient effect, showing a strong inhibitory action on the implantation and/or post-implantation as well as a teratogenic effect, being more efficient in the concentration of $0,60 \mathrm{~g} / \mathrm{ml}(\mathrm{P}<0.001)$.
\end{abstract}

Key words: abortifacient, reproduction control, ananai, rats.

Efeitos abortivos de Ananas ananassoides BAK. (Ananai) em ratos.

RESUMO - O chá da infrutescência (frutículo mais a casca) do ananai (Ananas ananassoides) foi administrado em ratas grávidas, no período de implantação dos embriões $\left(5^{\circ}-6^{\circ}\right.$ dia de gestação). Os animais foram sacrificados no $14^{\circ}-15^{\circ}$ dia de gestação e a média de implantes e reabsorções foi avaliada. Verificou-se que esta planta tem efeito abortivo, produzindo importante efeito inibitório na implantação e/ou pós-implantação e efeito teratogênico, principalmente a partir da concentração $0,60 \mathrm{~g} / \mathrm{ml}(\mathrm{P}<0.001)$.

Palavras-chave: Abortivos, Controle da reprodução, Ananai, Ratos

\section{INTRODUCTION}

Investigations into the effects of various plant and herb materials used by the ancient and native indians concerning fertility control purpose are currently quite common among the Amazonian communities. Among these materials, the Ananas ananassoides Bak. (Ananai) in the suspension form of tea, is generally recognized in the Amazon region of Brazil as having an abortive effect in women if used until the 12th week of gestation. Furthermore, other species of
Bromeliacea are currently considered as antifertility agents FARNSWORTH et al. (1975). It is well reported in humans and animals that the time during which each organ system in the body is being established, when obligatory inductive tissue interactions and morphogenesis are occurring, is called the critical period for that structures during the first few days of the development (WILMUT et al., 1986). In the rat the gestation period is 22-23 days and the developing of the embryo and the placenta occurs on the 13 days (BENNETT \& VICKERY, 1970)

1 Universidade Federal do Pará - Departamento de Biologia - Laboratório de Reprodução Animal - Belém, PA. 
and prenatal mortality is influenced by a number of factors including genotype, age and density of population (BRADFORD, 1969; SADLEIR, 1969).

Although the maternal placental foetal interactions avoid some potentially harmful factors that cause damage to the embryo, most of them such as radiation, many viruses, some steroid hormones and most of low molecular weight compounds such as vitamins, metabolic cofactors and their antagonists, ethanol and heavy metals have been reported as potential harmful for the embryo (NODEN \& DE LAHUNTA, 1985).

Reports on the effect of Ananas ananassoides on rodents had not been published so far. Thus, the aim of the present work was to test the effect of this vegetable on the fertility of rats.

\section{MATERIAL AND METHODS}

Sixty virgin female McCowley rats grouped in two batches of 30 animals (control and treated), for each concentration, originating from the same breeding line and bred in the same environmental conditions, were used in the present study. Between nine and fourteen weeks of age, vaginal smears were taken and examined every evening; those females that were in proestrus or early estrus were kept over- night with males of proven fertility in a 2:1 ratio. In the following morning, the observation of thick clumps of spermatozoa in the vaginal smear was an indication of first day of gestation. Each pregnant rat was kept isolated in a cage and submitted to an intraperitoneal injection of infrutecense (corresponding to the edible part plus its cover) ananai tea between 5-6th day of pregnancy in the following schedule:

Group A: $0.15 \mathrm{~g} / \mathrm{ml}$

Group B: $0.30 \mathrm{~g} / \mathrm{ml}$

Group C: $0.60 \mathrm{~g} / \mathrm{ml}$

The control animals selected out of the same breeding line received a sterile saline solution $(\mathrm{NaCl} 0.9 \%)$ in the same schedule as the treated animals. All females were sacrificed on the 14-15th day through overexposure to ether inhalation and submitted to laparotomy for collection of the genital system. The ovaries were removed for counting corpora lutea and the uterus was exposed for the assessment of total implants, dead implants and live foetuses. The foetuses were placed in saline solution and examined on stereomicroscope for detection of gross developmental malformation.

For the calculation of the Loss of Implanted Rats - LIR, Reabsorption Rates - RR and Loss of Embryos per Rats - LER where used the following equations:

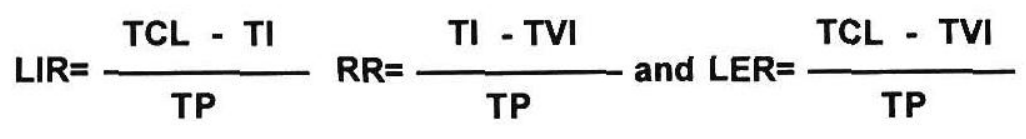


$\mathrm{TCL}=$ Total Number of Corpora Lutea

TI $=$ Total Number of Implanted Implanted

TVI $=$ Total Number of Viable

$\mathrm{TP}=$ Total Number of Pregnant Rats

The results were statistically evaluated by the variance analysis and t-test (STATISTICAL ANALYSIS SYSTEMS INSTITUTE).

\section{RESULTS}

The experimental results were summarized in Tables 1, 2 and 3.

The number of gestational corpora lutea has been used as a good evidence for ovulation pattern (INMAN \& MARKIVEE, 1963). Furthermore, it is possible to stress the embryotoxic effect of the ananai comparing the number of corpora lutea with the number of viable implanted. The LER phenomena has been observed from the ovulation through the implantation, even in the control groups. Moreover, as was observed through the variance analysis it was not observed a significant difference in relationship with the embryo loss, for the three female rat control group. The less efficient ananai concentration was $0.15 \mathrm{~g} / \mathrm{ml}$, which presumed that lower concentration did not induce abortifacient effects:

\section{DISCUSSION AND CONCLUSIONS}

LASZLO \& HENSHAW (1954) cited the presence of a substance in unripe Ananas comosus and Ananas

Table 1. Implantation rate loss for pregnant rats among each treated group and its respective control (t-TEST).

\begin{tabular}{|c|c|c|c|c|c|}
\hline Group & $\begin{array}{l}\text { Pregnant } \\
\text { Rats }\end{array}$ & $\begin{array}{l}\text { Total } \\
\text { Corpora } \\
\text { Lutea }\end{array}$ & $\begin{array}{c}\text { Total } \\
\text { Implanted }\end{array}$ & LIR* & t-TEST \\
\hline$A_{c}$ & 8 & 71 & 67 & 0.50 & \multirow{2}{*}{$1.27^{\mathrm{NS}}$} \\
\hline$A_{1}$ & 12 & 115 & 101 & 1.17 & \\
\hline$B_{c}$ & 26 & 229 & 217 & 0.46 & \multirow{2}{*}{$6.35^{\circ}$} \\
\hline$B_{t}$ & 22 & 194 & 145 & 2.23 & \\
\hline $\mathrm{C}_{\mathrm{c}}$ & 21 & 174 & 159 & 0.71 & \multirow{2}{*}{$5.33^{\circ}$} \\
\hline$c_{t}$ & 21 & 212 & 129 & 3.95 & \\
\hline $\begin{array}{l}A_{i}=0.1 \\
A_{c} B_{c} a \\
N S=N \\
\text { LIR }^{*}=\end{array}$ & $\begin{array}{l}/ \mathrm{ml} \\
\mathrm{C}_{\mathrm{c}}=\mathrm{co} \\
\text { Signific } \\
\mathrm{s} \text { of } \mathrm{Im}\end{array}$ & $\begin{array}{l}\quad B_{1}=0 \\
\text { group } \\
=V e=V e \\
\text { ited Rats }\end{array}$ & . & $C_{t}=$ & $0.60 \mathrm{~g} / \mathrm{m}$ \\
\hline
\end{tabular}


Table 2. Presentation of reabsorption rates for rats among each treated group and its respective control (t-TEST).

\begin{tabular}{|c|c|c|c|c|c|}
\hline Group & $\begin{array}{l}\text { Pregnant } \\
\text { Rats }\end{array}$ & $\begin{array}{c}\text { Total } \\
\text { Implanted }\end{array}$ & $\begin{array}{c}\text { Viable } \\
\text { Implanted }\end{array}$ & $\mathrm{RR}^{*}$ & t-TEST \\
\hline$A_{c}$ & 8 & 67 & 62 & 0.62 & \multirow[b]{2}{*}{$0.11^{\text {NS }}$} \\
\hline$A_{t}$ & 12 & 101 & 94 & 0.58 & \\
\hline$B_{c}$ & 26 & 217 & 201 & 0.61 & \multirow{2}{*}{$1.48^{\mathrm{NS}}$} \\
\hline$B_{t}$ & 22 & 145 & 124 & 0.95 & \\
\hline $\mathrm{C}_{\mathrm{c}}$ & 21 & 159 & 148 & 0.52 & \multirow{2}{*}{$3.38^{\circ}$} \\
\hline $\mathrm{C}_{\mathrm{t}}$ & 21 & 129 & 96 & 1.57 & \\
\hline $\begin{array}{l}A_{t}=0.1 \\
A_{c} B_{c} \text { ar } \\
N S=N \\
R^{*}=R\end{array}$ & $\begin{array}{l}\mathrm{g} / \mathrm{ml} \\
\mathrm{d} \mathrm{C}_{\mathrm{c}}=\text { cont } \\
\text { n-Significa } \\
\text { eabsorption }\end{array}$ & $\begin{array}{l}\qquad B_{t}=0.2 \\
\text { group } \\
\text { Rates }\end{array}$ & $0 \mathrm{~g} / \mathrm{ml}$ & $C_{t}=$ & $0.60 \mathrm{~g} / \mathrm{ml}$ \\
\hline
\end{tabular}

Table 3. Relationship of rat embryos loss among each treated group and its respective control (t-TEST).

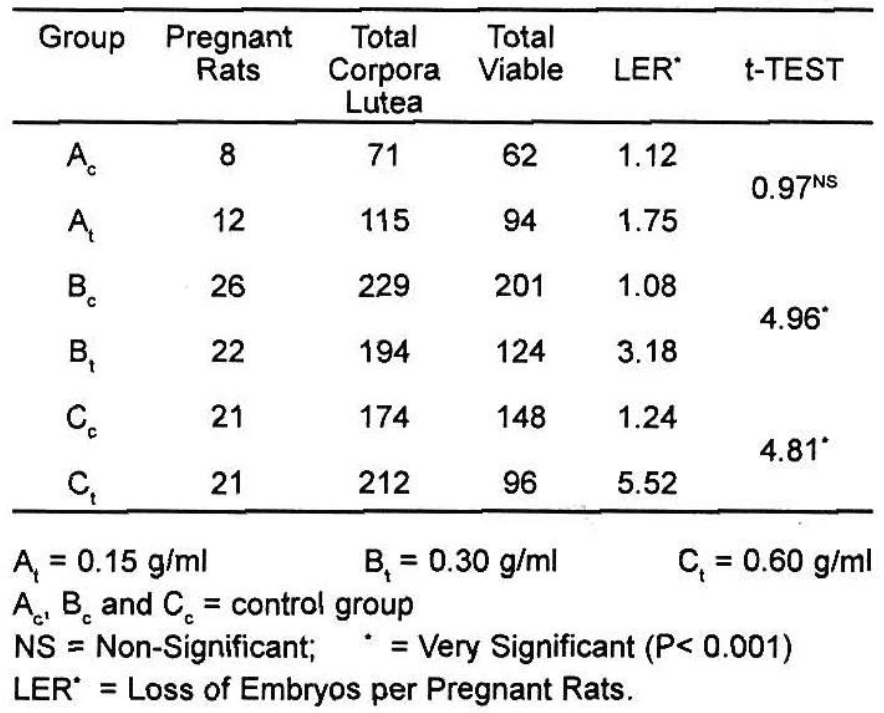

sativus juices, that drinking fresh or taking raw, would interfere on the implantation or in development of the pregnancy
(PATON, 1968; FARNSWORTH et al., 1975). Those substances could have estrogenic activity (FEURT \& FOX, 1955) 
and/or stimulate uterine tissue either in vitro or in vivo, through the amine, 5-hydroxytryptamine (FARNSWORTH et al., 1975) and/or having an ecbolic activity through the bromelain, proteolytic enzyme from the pineapple plant (NAKANISHI \& AOYAMA, 1980).

The anti-implantation activity of Ananas comosus was showed that $40 \%$ of the implants only were detected after rats had been treated on 1-7 day of pregnancy (GARG et al., 1970).

NAKAYAMA et al. (1987) found that Ananas ananassoides tea has, in the same concentrations used in the present study, clastogenic and mutagenic effects in the bone narrow cells of the Mus musculus specie. But the same tea in mice has not done a teratogenic effect on the begin of the embryo (1 to 3) days of development (NAKAYAMA et al., 1992).

On the other hand, the present study showed that the administration of ananai in 5th to 6th day of pregnancy increase the rates of LIR, RR and LER (Tables I, II and III). The LIR phenomena were more effective at $\mathbf{0 . 3 0}$ $\mathrm{g} / \mathrm{ml}$ and $0.60 \mathrm{~g} / \mathrm{ml}$.

The $\mathbf{R R}$ was significant only at $0.60 \mathrm{~g} / \mathrm{ml}(\mathrm{P}<0.01)$. It was observed also on this concentration a total loss of foetus which were found in some cases inside the uterine horns, phenomena which was not observed among 55 control animals.

These observations suggested that ananai could affect the implantation period and/or after that.

LIR, RR and LER were ob- served even in the control groups (Tables I, II and III), but the variance analysis showed that there was not a significant difference these parameter in control groups. The reserve of control groups for each concentration studied was not necessary suggested that control rats comprised a homogeneous population.

In mammals, under natural conditions, the LIR, RR and LER could be leaded through three factors: 1 . Development of abnormal embryos; 2 . The maternal environmental may be unable to support normal development of embryo; 3. An inappropriate relationship between the embryo and the mother, the mother and conceptus. In the present study, such problems could be occurred as a normal fact, however not in a frequency that could interfere on the results (WILMUT et al., 1986).

Embryos may be abnormal, in non-t-eated animals because of inherited defects, due to errors at meiosis or fertilization, as well as through environmental factors which have a direct effect on the embryos (WILMUT et al., 1986). Regarding the Ananas ananassoides treated groups, the teratogenic effects of the drug also must be considered due the presence of three undeveloped foetus in $0.60 \mathrm{~g} / \mathrm{ml}$ concentration. The small percentage of malformed foetus may be attributed to less evident abnormalities which could have pass undetected. On the other hand, the teratogenic effects could have been masked by the high foetal losses observed, for example during selective loss of genetically abnormal embryos. 


\section{ACKNOWLEDGMENTS}

The authors are grateful to Dr. Manuel Ayres for statistical analysis of the results, Dr. José Ricardo S. de Souza for the critical reading of this manuscript, Miss Lúcia F. Almeida for technical assistance and Dr. Oswaldo Frota Pessoa for encouragement and constructive suggestions. This work was supported by FADESP -UFPa.

\section{References}

BENNETT, J.P;; VICKERY, B.H. 1975. Rats and Mice. In HAFEZ REPRODUCTION AND BREEDING TECHNIQUES FOR LABORATORY ANIMALS. Lea \& Febiger, Philadelphia-USA.

BRADFORD, G.E. 1969. Genetic control of ovulation rate and embryo survival in mice. 1. Response to selection. Genetics, 61:905-921.

FARNSWORTH, N.R.; BINGEL, A.S.; CORDELL, G.A.; CRANE, F.A.; FONG, H.H.S. 1975. Potential value of plants as sources of new antifertility agents.I. $J$. Pharmac. Sci., 64(4):535-598.

FEURT, S.D.; FOX, L.E. 1955. Report on wax from several species of Tillandsia and from Ananas comosus (L.) Merr. Science, 121:42.

GARG, S.K,; SAKSENA, S.K.; CHAUDHURY, R.R. 1970. Antifertility screening of plants part VI. Effect of five indigenous plants on early pregnancy in albino rats. Indian J. Med. Res., 58(9):1285-1289

INMAN, O.R.; MARKIVEE, C.R. 1963.
Gross effects on rabbit embryos and newborn of X-irradiation in the blastocyst stage. Anat. Rec., 147:139.

LASZLO, H.; HENSHAW, P.S. 1954. Plant materials used by primitive peoples to affect fertility. Science, 119:626-631.

NAKANISHI, M.; AOYAMA, T. 1980. The effects of Bromelain on labor. Acta Obst. Gynaec. Jpn., 32(6):806-810.

NAKAYAMA, L.; AMORIM, M.I.M. 1987. Estudos preliminares dos efeitos do chá de Ananas ananassoides Bak. (Ananai) sobr s células de medula óssea de camundongo Mus musculus. Ciência e Cultura, 39(7):739.

NAKAYAMA, L.; NANBA, S.Y.; VALE, W.G. 1992. Avaliação do chá de Ananas ananassoides Bak. (ananai) nos estágios iniciais do desenvolvimento de Mus musculus. XIX Congresso Brasileiro de Zoologia e XII Congresso LatinoAmericano de Zoologia: 155.

NODEN, D.M.; DE LAHUNTA, A. 1985. The embryology of domestic animals-Developmental mechanisms and malformations. Williams \& Wilkins. BaltimoreUSA.

PATON, D.M. 1968. The contractile response of isolated rat uterus to noradrenaline and 5-hydroxytryptamine. Eur. J. Pharmacol., 3:310-315.

SADLEIR, R.M.F.S. 1969. The Ecology of Reproduction in Wild and Domestic Mammals. Methieen-England.

STATISTICAL ANALYSIS SYSTEMS INSTITUTE. 1982. SAS user's guide statistics 82, Raleigh.

WILMUT, I.; SALES, D.I.; ASHWORTH, C.J. 1986. Maternal and embryonic factors associated with prenatal loss in mammals. J. Reprod. Fert., 76:851-864. 